Journal of Jungian Scholarly Studies

Vol. 8, No. 9, 2012

\title{
Jung, History and His Approach to the Psyche
}

\author{
Kevin Lu, Ph.D. \\ University of Essex
}

In an article published almost two decades ago, Andrew Samuels (1996) describes various ways in which Jungian studies might thrive within universities. One approach that has flourished is the application of analytical psychology to other disciplines in the hope that Jungian ideas might shed light on a particular problem with which each discipline has grappled. There is a danger, however, that these attempts at "applied psychoanalysis" degenerate into "wild psychoanalysis," denoting an approach failing to recognize the unique epistemology and methodology of the field onto which depth psychological insights are being applied (Elms, 2003). Championing the virtues of depth psychology consequently overshadows the aim of dialogue between disciplines, leading to an often-made critique that ventures in "applied psychoanalysis" are reductive, essentializing and simplifying that which is ultimately complex (Barzun, 1974; Stannard, 1980). For Samuels (2010), the more productive and realistic effort lies in situating one's work at the interface of depth psychology and the other discipline in question. A middle ground between the two disciplines, therefore, needs to be established. By building a foundation that may connect them, a depth psychological intervention into the field is made more tenable.

The aim of this paper is to work at the interface of the disciplines of history and analytical psychology, in the hopes that greater dialogue between the two will be facilitated. First, I use the debate surrounding Petteri Pietikainen's (1998) paper, "Archetypes as Symbolic Forms," as a springboard to my argument that a depth psychological intervention into analyses of culture, society and subsequently the discipline of history is indeed warranted, timely, and necessary. To buttress this paper's contention, I highlight the ways in which Jung drew on "history" in formulating his model of the psyche. I then explore how Jung's approach may be deemed historical, and finally I critically assess the extent to which he relied on his understanding of history to define key analytical psychological concepts.

Jung's interest in, and even appreciation for, the discipline of history, however, does not mean that he responsibly conducted historical analyses or that his method is entirely historical, especially as it is understood by practicing historians both past and present. To confuse Jung's interest in, and intuitions about, history for a tested 
method of historical analysis would ignore the discipline's own debates on the nature of history (Carr, 1961/1990; Elton, 1969/1987), evaluations of its epistemologies and methodologies (Jordanova, 2000/2006), the effect postmodern thinking has had on destabilizing historical knowledge (Jenkins, 1991/2008; Munslow, 1997), and how practicing historians have in turn defended their craft against the rise of rampant relativism (Evans, 1997; Marwick, 2001). What my analysis does elucidate is the extent of Jung's interest in history, which in turn provides $a$ justification (but by no means an unproblematic one) for exploring the possible contribution of analytical psychology to the discipline of history. ${ }^{1}$ Certain analytical psychological concepts and "Jungian" ways of working are deeply historical and, by extension, lend themselves to analyses of culture. Yet without the preliminary step of establishing what it is in Jungian thought that may be deemed historical, responsible forays into a Jungian contribution to psychoanalytic history —as opposed to psychohistory — may prove difficult (Lu, 2011). ${ }^{2}$

This brings me to my first point - my paper is not the first to explore questions surrounding the applicability of analytical psychology to historical and sociocultural analysis. Notably, Pietikainen (1998) argues against the ahistorical nature of Jung's original conception of archetypes (as a priori [Jung, 1918/1970, p. 10]), and contends that the only way to salvage the concept is to concentrate on the archetypal image, that is, the expression of an archetypal pattern in consciousness that is shaped by a given historical and social context (Jung, 1947/1960; 1958/1970; 1938/1959).

1 It could be argued that Jung, in many of his works, was showing an interest in "history." One example would be his essay on "Wotan," where he argues that the wandering, German god of storm and frenzy, as an archetypal expression, was constellated during the Nazi era. This, then, explains how "[the] Hitler movement literally brought the whole of Germany to its feet, from five-year-olds to veterans, and produced the spectacle of a nation migrating from one place to another" (Jung, 1936/1988, p. 11). I suggest, however, that this is not Jung "doing" history. This is Jung responding to a salient and contemporary political event. He was in the midst of it, not looking back into the past from a different vantage point. Other texts that might evidence Jung's approach to writing history include Symbols of Transformation (1956/1976) and Aion (1959/1978). As I will endeavour to show, however, what Jung presented in these texts is not "history" as historians understand it today but a perspective on the psyche influenced by the concept of history.

2 I proposed, along the lines originally suggested by Ludmilla Jordanova (2000/2006), that psychohistory is a term we might use to identify those projects in "applied psychoanalysis" that place at its center the theories of depth psychology and that largely ignore the issues with which practicing historians grapple. Such studies would too narrowly utilize a particular depth psychological lens and, accordingly, would advance the efficacy of its chosen perspective to comment upon historical events and collective phenomena. Psychoanalytic history, on the other hand, might be used to denote those studies in which depth psychological perspectives are used cautiously and judiciously. They would not be the "centerpiece" of the study but would provide tools historians could use in attempting to recreate a past with which they are engaged. The focus here, then, would be on writing history, telling responsible narratives of the past that are ultimately constrained by the available sources. Depth psychological analyses would only be undertaken if the subject invites such an interpretation and only ever as a supplement to, and deepening of, historical explanation. Some examples of psychoanalytic history can be found in the historical study of witchcraft (Briggs, 1996; Demos, 1982; Purkiss, 1996/1997; Roper, 1994). 


\section{$3 L u$}

Pietikainen's contention met with much resistance. Anthony Stevens (1998), for instance, defended the biological foundations of analytical psychology and argued that Pietikainen's anthropological view of symbols - that "they are to be understood as wholly derived from the social context in which they arise"contrasts with Jung's contention that humanity possesses an innate capacity to form symbols (p. 345). George Hogenson (1998) challenged Pietikainen's reading of Ernst Cassirer, whose philosophy Pietikainen drew from to frame his argument (p. 357), and suggests that both Stevens and Pietikainen fail to address a more significant problem, which is "the relationship between biology and culture in Jung's thought" (ibid., p. 358). Hester McFarland Solomon (1998) accused Pietikainen of extracting "from Jung's theory what is particularly exciting about it, that is, its capacity to bridge the two disciplines of science and the humanities" (p. 374). What results is an overvaluation of the hermeneutical method at the expense of a more holistic approach. Ultimately, McFarland Solomon emphasized that Pietikainen's approach is purely academic and not clinical. A clinical approach acknowledges the importance of biological development in the individual life cycle (ibid., p. 375). These responses led Pietikainen to place little hope in a reconfiguration of archetypal theory that serves historical and socio-cultural analysis (1998a). ${ }^{3}$

While the merits of his detractors' arguments are duly noted, and given the publication of recent articles by Christian Roesler (2012) and Harry Hunt (2012) both of whom question the biological foundations of analytical psychology and who imply (whether implicitly or explicitly) the important role played by society and culture in Jung's thinking and analytical psychology's place among the social sciences - my aim here is to highlight the importance of Pietikainen's argument, showing that history, society and culture were not themes anathema to the multiple ways in which Jung envisioned his approach to the psyche. Rather, they were integral to it.

\section{Defining history}

What is meant by the term "history" as practiced by professional historians today needs to be established. Simply defined, history may be referring to "the past," and historians are "those who study and write about history" (Warren,

\footnotetext{
${ }^{3}$ Greg Mogenson (1999), in the final response to the thread, raised concerns about the extent to which analytical psychology was caricatured in the debate. "Does analytical psychology," he asks, "really have to major in evolutionary psychology and bone up on philosophy? Or can it [...] give primary attention to the manifestations of the psyche and contribute to the understanding of archetypes from its own psychological perspective?" ( $p$. 126).
} 
1999/2004, p. 109). William Dray (1964) defined history as referring to both the course of events and the writing of history (p. 1). Aviezer Tucker (2004) similarly defined history as either past events or the study of past events (p. 1). These definitions, however, conflate "history" with "the past." As John Warren (1999/2004) points out, in practice, history is about the "actual writing about the past by historians, rather than the past itself' (p. 109).

Arthur Marwick, taking a more empiricist view of history (1995), defined the discipline as " $[t]$ he bodies of knowledge about the past produced by historians, together with everything that is involved in the production, communication of, and teaching about that knowledge" (2001, p. 290). History is, indeed, not the past, but the cumulative work of historians about the past. Historians, further, do not merely reconstruct the past but "produce knowledge about the past" (ibid., p. xiii, emphasis in original). History is based on evidence and does not proceed on either speculation or the imposition of a metatheory in which facts are forced to fit a structure. Marwick asserts that historical knowledge ultimately stems from an engagement with primary documents and that secondary sources, though important, should only serve in aiding our interpretation of primary sources (ibid., p. 28). Marwick, however, may be overstating the importance of primary sources. Historians deal with a vast amount of material, and it is impossible for them to read all the primary sources connected to their specific area of study. So long as the secondary sources under consideration are scrutinized and meet the standard of rigorous historical scholarship, they can provide useful synopses crucial to the historian's research. Both Ludmilla Jordanova (2000/2006) and Keith Jenkins (1991/2003) also note that depending on the situation, primary sources can be secondary and vice versa.

For John Tosh (1984/2010), the aim of academic history is not to establish the "truth" in an absolute sense but an "incremental growth in our knowledge of the past" (p. ix). He outlined four goals to which historians, to varying degrees, have aspired: "to discover what happened in the past and what it was like to live in the past [...];" to seek out the patterns and teleological goal of history; to see history as inextricably intertwined with political objectives; and to distil unique insights and lessons arising from the historical record itself (ibid., pp. 2-7). In extreme forms, however, any one of these goals has the potential of becoming unhistorical, especially if a commitment to a particular argument or theory eclipses an obligation to being constrained by the available sources.

A staunch commitment to the sources does not preclude the possibility of bias-reading historical documents in a certain manner, to serve a particular purpose. For Jordanova (2000/2006), bias only becomes a problem "when it prevents historians from being judicious and from having a measure of creative, critical distance from their work" (p. 3). Unbiased history is impossible, but a more balanced, self-aware history is not. Yet the passions that drive historians to study 


\section{$5 \quad L u$}

the areas they do needs to be tempered with evidence. An important practice that needs to be cultivated in the discipline of history is critical distance, though this can lead to impersonal accounts that are no more desirable than those fuelled by passion alone. For Jordanova, though it is difficult to provide a concise definition of history upon which all practicing historians can agree, among the discipline's most valued qualities are "eclecticism and analytical flexibility," and engagement with 'diverse sources and approaches to produce more holistic accounts' (ibid., p. 4).

Admittedly, the perspectives of three respected historians on the discipline of history do not exhaust what all historians think history is about. Yet, given these assessments and having studied the debates on the nature of history, I offer the following definition:

a) History is not the past. The past is ultimately irretrievable, since the traces of the past with which we are left are incomplete and problematic in their own right.

b) History encompasses studies of the past undertaken by historians (based largely on a close reading of primary sources, knowledge of pertinent secondary sources, and an expertise in recreating the contexts in which their topic is situated), so long as these works meet the standard of historical research agreed upon by the profession (that is, they cannot be falsifications of the historical record [Evans, 2002]).

c) History has benefited immensely from postmodern critiques, especially pertaining to the language and rhetoric used by historians, and the role subjectivity plays in writing and narrating the past (Jenkins, 1991/2008; Munslow, 1997/2006). However, historians still need to be faithful to the sources, and one cannot impose a narrative or dictate a certain interpretation if the sources do not permit it.

In defining history, it may be apparent that analytical psychology begins from a different epistemological position. History, in large part, deals with events and occurrences of the past, and what it may have been like to live in a past reality based on extensive knowledge of its cultural context. Depth psychology is concerned with the unconscious, its interaction with consciousness, and how this affects individual personalities. ${ }^{4}$ History's approach to understanding past events is

\footnotetext{
${ }^{4}$ That is not to say, however, that different strands of depth psychology have not developed theories of groups (Armstrong, 2005; Behr \& Hearst, 2005; Bion, 1952; Foulkes, 1965; Frosh, 2010; Hinshelwood, 1997; Jacques, 1953; Skynner, 1991).
} 
inherently rational, while depth psychology tends to focus on underlying irrational dynamics. In other words, history operates almost exclusively at the conscious level, whereas depth psychology is more concerned with the unconscious. These epistemological differences must be noted, but they do not preclude the possibility that depth psychological insights can contribute to historical knowledge. Without employing the language of psychology, historians are all too often willing to provide explanatory ideas about behaviour outside a historical personality's conscious will. To emphasize the dissimilarities, further, would prevent an exploration of the ways in which depth psychology's methodology may in fact be historical. With the working definition of history I have provided in mind, I want to highlight the ways in which "history" found its way into the very fabric of analytical psychology.

\section{Jung's conception of the psyche}

Jung (1963/1989) recounts a dream to Freud during their tour of America in 1909 that contained allusions to collective contents and highly symbolic material. Freud, however, was only able to elucidate, in Jung's opinion, a small fraction of its import and potential meaning:

I was in a house I did not know, which had two stories. It was 'my house.' I found myself in the upper story, where there was a kind of salon furnished with fine old pieces in rococo style. On the walls hung a number of precious old paintings. I wondered that this should be my house, and thought, 'Not bad.' But then it occurred to me that I did not know what the lower floor looked like. Descending the stairs, I reached the ground floor. There everything was much older, and I realized that this part of the house must date from about the fifteenth or sixteenth century. The furnishings were medieval; the floors were of red brick. Everywhere it was rather dark. I went from one room to another, thinking, 'Now I really must explore the whole house.' I came upon a heavy door, and opened it. Beyond it, I discovered a stone stairway that led down into the cellar. Descending again, I found myself in a beautifully vaulted room which looked exceedingly ancient. Examining the walls, I discovered layers of brick among the ordinary stone blocks, and chips of brick in the mortar. As soon as I saw this I knew that the walls dated from Roman times. My interest by now was intense. I looked more closely at the floor. It was of stone slabs, and in one of these I discovered a ring. When I pulled it, the stone slab lifted, and again I saw a stairway of narrow stone steps leading down into the depths. These, too, I descended, and entered a low cave cut into the rock. Thick dust lay on the floor and in the dust were scattered bones and broken pottery, like remains of a primitive culture. I discovered two 
human skulls, obviously very old and half disintegrated. Then I awoke (pp. 158-159). ${ }^{5}$

In his interpretation, Freud concentrates on the two skulls. Jung initially suggests that the two skulls might belong to his wife and sister-in-law. In retrospect, Jung understands the dream to image his eventual model of the psyche:

It was plain to me that the house represented a kind of image of the psyche [...] Consciousness was represented by the salon. It had an inhabited atmosphere, in spite of its antiquated style.

The ground floor stood for the first level of the unconscious. The deeper I went, the more alien and the darker the scene became. In the cave, I discovered remains of a primitive culture, that is, the world of the primitive man within myself - a world which can scarcely be reached or illuminated by consciousness [...] The dream pointed out that there were further reaches to the state of consciousness I have just described: the long uninhabited ground floor in medieval style, then the Roman cellar, and finally the prehistoric cave. These signified past times and passed stages of consciousness. [...] It [Jung's dream] obviously pointed to the foundations of cultural history - a history of successive layers of consciousness. My dream thus constituted a kind of structural diagram of the human psyche; it postulated something of an altogether impersonal nature underlying that psyche (ibid., pp. 160-161, emphasis in original).

Jung explains the difference between his own and Freud's interpretation of the house dream as stemming from the respective contexts in which they were situated. Jung had "grown up in the intensely historical atmosphere of Basel at the end of the nineteenth century," no doubt referring to the influential presence of the prominent historian, Jacob Burckhardt (ibid., pp. 160-161). This "historical atmosphere" in turn shaped Jung's approach to dream analysis and his relationship to the contents of the unconscious. ${ }^{6}$ When engaging with dreams and psychic

\footnotetext{
${ }^{5}$ Though the problems of authorship, omissions, and "auntification" raised by Sonu Shamdasani (1995) and Alan C. Elms (1994) are duly noted, Shamdasani has relayed that despite the limitations of relying on MDR as an authentic source of Jung's ideas, the individual paragraphs are generally faithful to Jung's own perspective, though undeniably shaped by whoever was imposing either their editorial corrections or comments (Marlan, 2006, p. 291, n. 1). As we shall see, this is not the only instance where Jung envisions the psyche to be comprised of historical stratifications.

${ }^{6}$ Richard Noll (1994/1997) indirectly suggests that Jung's interest in "history" is a remnant and consequence of his adherence to Ernst Haeckel's biogenetic law (p. 48, 52). Haeckel, writes Noll, insisted that "evolutionary biology was a historical science involving the historical methodologies of embryology, paleontology, and especially phylogeny" (ibid., p. 48, emphasis in original). By extension, Jung's penchant for the "historical" is not in actual fact an interest in the discipline of history. The extent to which this is true needs to be explored further,
} 
images, he "never did so without making historical comparisons" (ibid., p. 161). Whereas, according to Jung, Freud's approach is highly personal in nature, Jung links the image's existence and impact to "general historical assumptions" (ibid.). The house dream, Jung concludes, obviously points to "the foundations of cultural history - a history of successive layers of consciousness" (ibid.). In retrospect, the dream (regardless of whether it was merely a reconstructed fantasy serving a specific purpose [Jones, 2007]) is an intuition pivotal to the foundations of Jung's psychology, one that would be corroborated throughout the course of his work. "It was my first inkling," he recalls, "of a collective a priori beneath the personal psyche" (Jung, 1961/1989, p. 161). "History" and Jung's conception of psychological traces of the past thus form a cornerstone to the way in which he conceives his model of the psyche.

This does not necessarily mean that Jung's conception of history-as an expression of archaic levels beneath consciousness - coincides with the definition of history (as it has been defined by historians) outlined above. In a previous book chapter, I argued that in many instances, when Jung cites "history," he is pointing to an archetypal form of history embedded in the unconscious - one awaiting the most opportune moment to express itself in consciousness. Historical events are thus trivialized, and true historical knowledge, for Jung, entails excavating the unconscious for the core pattern being constellated. Jung's understanding of history, in fact, can be classified as belonging to a particular branch of the philosophy of history-speculative philosophy of history ( $\mathrm{Lu}, 2011)$. Indeed, such an understanding of the past opposes the realm of the historical as recognized by the discipline of history (as defined by practicing historians) because a) it is not supported by what would be acceptable as either primary or secondary evidence and b) because it does proceed on speculation (that the greater form of history informing historical events is an archetypal pattern) and imposes a metatheory (i.e., the collective unconscious) in which facts are forced to fit a structure. How analytical psychology might overcome these limitations and inform historical practice will be an issue I touch on briefly in my conclusion. For my present purpose, given the fact that Jung evoked and drew upon the discipline of history to frame his understanding of the dynamics and structure of the psyche, one should refrain from "throwing the baby out with the bathwater;" in attempting to grasp the nature of what he was experiencing, Jung could not help referring to "history" to contain and shape knowledge. This suggests that Jung's appreciation for the discipline of history-perhaps as it had been presented in Burckhardt's The

\footnotetext{
though I believe sufficient evidence exists to suggest that in many cases, when Jung evoked history, he was indeed expressing his interest in the discipline of history (Lu, 2011).

${ }^{7}$ Lucy Huskinson (2013) argues that the house dream provides an architectural metaphor intuiting "a lived experience of [psyche]," not merely presenting "a conceptual consideration of psyche" (p. 64).
} 


\section{$9 \quad L u$}

Civilization of the Renaissance in Italy (1860/1995) - requires greater attention, despite Jung's insistence that Burckhardt was merely a "side influence" (de Angulo, 1977/1978, p. 207).

Jay Sherry (2010/2012) remarks that Burckhardt was "a one man cultural institution" (p. 26) - a "kind of patron saint of Basel" (Gossman qtd. in Sherry 2010/2012, p. 26). Jung's comments concerning Burckhardt support such an interpretation. Jung states that "Burckhardt was our daily bread" (Jung qtd. in de Angulo, 1977/1978, p. 207) and, whilst reminiscing on his past, remembers "the days when Bachofen and Burckhardt walked in the streets [...]" (Jung, 1963/1989, p. 111). It was from Burckhardt that Jung borrowed the term primordial image, ${ }^{8}$ which would later be known as, and reformulated into, the archetype in Jung's psychology. Jung's indebtedness to Burckhardt has been noted by many scholars (Clarke, 1992, p. 80; Shamdasani, 2003/2004; Sherry, 2010/2012; Wolff-Windegg, 1976), though none perhaps more eloquently than Ira Progoff (1953/1985):

From [...] Jacob Burckhardt, [Jung learned to assimilate] an historical point of view which could be applied to the modern situation [...] Burckhardt's writings were read and studied as a matter of course; it was part of being a citizen of Basle. Jung absorbed Burckhardt's historical orientation, then, not because he was a close student of society during his early years, but because Burckhardt's work and insights were part of the cultural atmosphere. Without consciously taking over any specific doctrines, the historical way of thinking about all human phenomena became part of his underlying outlook, and later on it was a natural step for him to apply an historical point of view to the analysis of psychic phenomena. In this sense, Jung's work must be interpreted as being related to the great Burckhardt tradition, and as constituting an approach to the historical life of man made from the special point of view of Jung's psychological field of study (p. 34).

For Jung (1963/1989), "body and soul" and by extension, his conception of the psyche, indeed possess "an intensely historical character" (p. 235).

Commenting on the house dream, Shamdasani (2003/2004) argues that it points to the fact that cultural history played a crucial role in the development of Jung's ideas (p. 138). ${ }^{9}$ Dreams, according to Jung, reveal both personal and

\footnotetext{
${ }^{8}$ Although Jung encountered the concept through Burckhardt, the term "primordial image" had been used since the seventeenth century (Shamdasani, 2003/2004, p. 298).

${ }^{9}$ According to Anna Green (2008), there are three major characteristics of cultural history that make it unique: "the focus upon human subjectivity; a holistic approach to culture that seeks to identify the unifying structures, patterns, or systems that connect the whole; and an interpretive, hermeneutic approach" (p. 10). Peter Burke notes, however, the difficulty in defining cultural history, for culture itself is constantly shifting. Accordingly,
} 
cultural memories, thus making them a possible doorway into cultural history (ibid.). Jung's emphasis on cultural history is further evident in a letter he sent to Freud in 1909. He writes that it had become clear to him that the problems of neurosis and psychosis could not be solved without mythology and cultural history (ibid.; Freud \& Jung, 1974, 170J). ${ }^{10}$ Jung's emphasis on cultural history is further evident in what he considers the central text that precipitated his break with Freud (Symbols of Transformation) and in which he first clarifies his theoretical differences. Here, Jung proposes that the time has come for psychoanalysis to shift its focus away from individual psychology, concentrating instead on how historical materials might illuminate the inner life (Shamdasani, 2003/2004, p. 140) . From my understanding, what Jung has in mind is not only a grasp of how archetypal imperatives are shaped by the contexts in which they arise but also how knowledge of the past (especially the history and development of symbols across different cultures) may shed light on difficulties in the present; cultural history and myth are mobilized to amplify individual, psychological processes (ibid., 140). Given Shamdasani's contention that cultural history was central to the development of Jung's psychology as a whole, it is not surprising that Jung acknowledges the importance of "history" in both his methodological approach and attitude towards analysis.

\section{The historical nature of Jung's methodological approach}

The first intimations of Jung's "historical" approach, that is, his acknowledgement that an awareness of the collective past is integral to personal psychology, are expressed to Freud in a letter dated November 30 to December 2, 1909. Jung stresses that a full understanding of the psyche requires history (meaning knowledge of the past), for what is found in the individual soul is, in microscopic form, a reflection of the historical past (Freud \& Jung, 1974, 165J). In this regard, the ethos of Jung's statement - that knowledge of the past aids in comprehending the present - parallels the historian E. H. Carr's (1961/1990) later assessment of history's importance - that it sheds light on the problems of the present (p. 26, 61). In another exchange, dated 12 June 1911, Jung comments that in dementia praecox (schizophrenia) "introversion leads not only, as in hysteria, to a recrudescence of infantile memories but also to a loosening up of the historical layers of the unconscious [...]" (Freud \& Jung, 1974, 259J). Jung's reservations about Freud's interpretation of Jung's house dream in 1909 are thus indirectly

cultural history can only be defined in terms of its own history (Burke qtd. in Green, 2008, p. 1). Cultural historians have thus been eclectic regarding their methodology, drawing from literary theory, psychology, anthropology, and linguistics (Green, 2008, p. 10).

\footnotetext{
${ }^{10}$ The original German term used by Jung, Kulturgeschichte, is translated by Shamdasani as "cultural history." In the Freud/Jung Letters, the term is translated as the "history of civilization."
} 


\section{$11 L u$}

expressed by 1911, with Jung making reference to the historical layers of the unconscious. What he means by "historical layers of the unconscious" would later be depicted in the mid 1920s, when he presented a diagram illustrating the many layers of the psyche, which included the family, clans, nations, and large groups (1925/1990, pp. 41-42).

In a presentation given in 1911, Jung (1911/1989) advises, as recorded by Otto Rank, that historical parallels (i.e., amplifications) are necessary for the comprehension of dementia praecox because its sufferers are overwhelmed by the "reminiscences of mankind" (p. 446). ${ }^{11}$ By "reminiscences of mankind," Jung might be alluding to the burden of the past, albeit at an archetypal rather than a strictly historical level. More importantly, it seems that Jung's burgeoning conception of what he would later call amplification is essentially based on a historical, comparative approach that places emphasis on knowing both the personal and social contexts of the analysand. ${ }^{12}$ In 1913, Jung (1973) expresses his interest in the discipline of history (among others) by encouraging greater dialogue with historians in a letter to the Psychoanalytic Review:

It is beyond the powers of the individual, more particularly of physicians, to

master the manifold domains of the mental sciences which should throw some light upon the comparative anatomy of the mind. Hence I would welcome as a most opportune plan the idea of the editors to unite in their journal the contributions of competent specialists in various fields. We need not only the work of medical psychologists, but also that of philologists, historians, archaeologists, mythologists, folklore students, ethnologists, philosophers, theologians, pedagogues and biologists (pp. 29-30).

Jung's recognition that a factor signaling his difference from Freud was their respective relationships to "history" (meaning the discipline, the respective contexts of their upbringing, and Jung's eventual formulation of the collective unconscious) was maintained throughout his career. In his 1948 address to the Jung Institute in Zurich, he outlines future projects that should be pursued from the perspective of analytical psychology, and among the first was a deeper exploration of Théodore Flournoy's contribution to "psychological biography" (Shamdasani,

\footnotetext{
${ }^{11}$ Jung (1936/1989) defines the principle of amplification as the act of seeking parallels, especially as it pertains to interpreting dream material. The aim is to elucidate what the imagery means for the analysand; to uncover its particular context or the "mental tissue" in which a particular term is embedded. Jung goes on to describe amplification as "the technique of finding the context" (p. 84). Such a concern for contextual analysis plays a pivotal role in defining the historian's craft.

12 This does not mean, however, that historical amplification as practiced by Jung and his followers matches the rigor of the historian's work. Jung (1943/1966) admits as much when he states that, though his work has a historical character, its limitation lies in the fact that it is essentially amateur history (p. 83).
} 
2003/2004, p. 345). Even near the end of his life, Jung maintains that his interest in "historical" material was a defining feature in the formulation of his own approach. Thus, in his Foreword to John W. Perry's The Self in Psychotic Process, Jung (1953/1989) writes:

$\mathrm{He}$ [Freud] was impressed with certain facts of neurotic psychology, which he even named after a famous mythological model, but I was overwhelmed with 'historical' material while studying the psychotic mind. From 1906 to 1912 I acquired as much knowledge of mythology, primitive psychology, and comparative religion as possible. This study gave me the key to an understanding of the deeper layers of the psyche and I was thus enabled to write my book with the English title Psychology of the Unconscious [later Symbols of Transformation] (pp. 354-355).

Again, one can question whether Jung is displaying an appreciation for historical artifacts and sources - the foundation of the historian's craft—or what can be described as Jung's interest in a distant past - the "archaic" or "primitive." Indeed, the exchange between Robert Segal (2007), Susan Rowland (2007), and Paul Bishop (2008) regarding Jung's understanding of the "primitive" and "archaic" might suggest that it is to this realm of the prehistoric past to which Jung's references to "history" point. As Pietikainen (2001) aptly observes, Jung's archetypal theory seeks to transcend historical time, rather than remain within its confines (p. 50). My interest, however, is in what lines of inquiry might be implicit in Jung's thinking based on observing what he said and how he worked and noting some of his intellectual precursors. Accordingly, this builds the foundation to consider how these insights - perhaps pending modification-might enrich and elucidate our engagement with other disciplines. Samuels once stated that he "often follows Jung's intuition as to which subjects will be important," but that he "often [finds] that [Jung's] methods and especially his conclusions, are wrong" (Samuels, personal communication, 2007). Based on Jung's numerous references to "history" and the emphasis he placed on the influence of the "historical atmosphere" of his upbringing, it would be wrong to ignore the historical character of analytical psychology. Indeed, as his method of amplification suggests, Jung recognized the importance of historical contextualization for his work. Whether he executed it with precision - as a practicing historian would - is up for debate and subsequent revision by Post-Jungians.

Alongside the principle of amplification, Jung's acknowledgment of the role played by context in shaping individual psyches - that is, displaying an acute historical sensibility - is evident in his critique of westerners turning to eastern practices. When one rejects the symbol system into which one was born, one's own identity is ultimately denied. To adopt another symbol set would be "playing our own history false," thereby covering "our nakedness with the gorgeous trappings of the East, as the theosophists do" (1934/1959, p. 14). For Jung, it would be more 


\section{$13 L u$}

worthwhile to work within one's own western (and predominantly Christian) context, even if one feels it to be impoverished. Although Jung does not completely devalue eastern practices such as yoga, the aim should be for westerners to develop a spiritual method that reaches the same goal as yoga, without inheriting the dangerous, intuitive means by which that goal had been reached. The West's command of disciplines like history acts as an intellectual container or "strongenough ego" mediating its engagement with the unconscious (Jung, 1929/1957, p. 43). There are, obviously, problems with the way in which Jung conceptualized the East and its practices (Clarke, 1994; Coward, 1985), but my point is that alongside Jung's universalizing tendencies was a deep respect for contextual analysis.

\section{The role of history in Jungian analysis}

When discussing the building of his tower at Bollingen, Jung (1963/1989) describes the process of working with the stone tablets, which evoked "the fateful link between me and my ancestors" (p. 233). He feels under the influence of "things or questions which were left incomplete and unanswered by my parents and grandparents and more distant ancestors" (ibid.). In relation to his own family, he senses an "impersonal karma" that passes from parents to children. "It always seemed to me," he states, "that I had to answer questions which fate had posed to my forefathers, and which had not yet been answered, or as if I had to complete, or perhaps continue, things which previous ages had left unfinished" (ibid.). What is not worked through presently "is paid for heavily in the next generation" (ibid., p. 215). For Jung specifically and depth psychology more generally, the past plays out, and continues to live, in the present.

Certainly, Jung was aware, as others after him have been (Abraham \& Torok, 1994; Ancelin Schützenberger, 1998/2009), that history (narratives of one's personal, familial, and collective pasts) shapes and informs an individual's identity. Jung (1963/1989) argues that we do violence to the present by distancing ourselves from our historical roots (pp. 235-236). The loss of a connection with the past is for Jung the reason for the rise of the "discontents" of civilization" (ibid., p. 236). A connection with the past, he reiterates, is crucial to the formulation of individuality and thus acts as a buffer to mass-mindedness (ibid.). "The less we understand of what our fathers and forefathers sought," he comments, "the less we understand ourselves, and thus we help with all our might to rob the individual of his roots and his guiding instincts, so that he becomes a particle in the mass [...]" (ibid.). Knowing one's past, what Jung refers to as "the historical family" (by which he ultimately meant the collective unconscious [Lu, 2011]), and how it resides in and plays out in each individual in the present, is crucial to psychological health. It is in humanity's best interest, then, to reconnect to this past, as the "ancestral psyches" 
within each of us can shed light on contemporary circumstances and situations (Jung, 1963/1989, p. 237). It is equally important, however, not to become lost in these past images, not to be "imprisoned in these memories" (ibid., p. 320).

Accordingly, in order to aid those in need, a therapist must know many histories (personal, familial, and collective) and must be prepared to reconstruct multiple histories during the course of therapy. Psychotherapists, Jung asserts, must particularly be aware of the "social atmosphere" (which I take to include predominant historical narratives and contemporary politics) of their culture (ibid., p. 234). The psyche is not merely a personal but "a world problem," and subsequently, the analyst "has to deal with an entire world" (ibid., p. 132). Personal problems are interconnected with collective ones and, at times, can be mistaken for what are ultimately disturbances in the realm of society (ibid., p. 234). It is to the latter that therapists need to look, a task, Jung surmises, that too few have taken up (ibid.). Jung (1947/1970), when articulating the need for therapists to be aware of "contemporary history" (pp. 177-178), means both the contemporary political climate and events of the recent past that will become historically significant (worthy of remembrance and thus likely to impact the psyche). Analysts today need to be, at the very least, amateur historians, being aware of their own histories and contexts, the cultural context in which analysis is taking place, and the various contexts of analysands (especially if they come from an ethnic background different to the one in which analysis is conducted). ${ }^{13}$ Without this knowledge, analysts are unable to grasp the symbolic language of the unconscious and are thus "unable to help his patient assimilate the irrational ideas" that confuse consciousness. This is the reason why, Jung explains, he collects historical materials, for which he has often been derided. It is not out of a "peculiar historical interest" that he collects "historical curiosities," but "an earnest endeavour to help the understanding of the diseased mind" (1953/1989, p. 356). Jung goes on to suggest that "[t]he psyche, like the body, is an extremely historical structure" (ibid., emphasis in original). These statements regarding Jung's approach to therapy suggest that he was highly sensitive to the ways in which individual identities are intricately connected to collective ones-the group's sense of cohesion founded upon shared, historical experiences. Jung, however, extends the concept of interconnectedness within cultural groups and envisions a realm of psyche built upon the accumulated experiences of all humanity-a realm to which all have access, irrespective of difference.

\section{The collective unconscious as a historical formation}

Given that Jung's approach to therapy acknowledges the import of the past, it is not surprising that in defining key concepts in analytical psychology, he looked

\footnotetext{
${ }^{13}$ Murray Stein aptly observes that the analyst is, in therapy, a type of biographer and historian (1987, p. 52).
} 


\section{$15 L u$}

to history as a hermeneutical framework. As intimated in his house dream, he envisions the unconscious historically, as a realm of psychic life that records key events in the development of both the individual and the collective. Jung (1931/1960) describes the collective unconscious as "a deposit of all human experience right back to its remotest beginnings" (p. 157). ${ }^{14}$ In his lectures given at the Tavistock in 1935, he asserts that the unconscious contains "the great collective events of the time" $(1936 / 1989$, p. 63) and further emphasizes his conception of the unconscious as a storehouse of psychic fragments from the past:

Our mind has its history, just as our body has its history [...] Our unconscious mind, like our body, is a storehouse of relics and memories of the past [...] The brain is born with a finished structure, it will work in a modern way, but this brain has its history. It has been built up in the course of millions of years and represents a history of which it is the result. Naturally it carries with it the traces of that history, exactly like the body, and if you grope down into the basic structure of the mind, you naturally find traces of the archaic mind (ibid., p. 41).

Jung's definition of the unconscious in reference to "history" leads Shamdasani (2003/2004) to assert that "the collective unconscious [represents] the eternal return of history in the soul" (p. 238). He further comments that, for Jung, "the soul was a historical formation" and that Jung locates history in the soul (ibid, p. 219). Murray Stein (1987) also observes that the unconscious can, in some instances, act like a time-keeper, recording important events even if consciousness attempts to suppress their memory (p. 59). As a connection to, and engagement with, both the personal and the collective unconscious are crucial to psychological health, one's engagement with them is simultaneously an engagement with a personal and a collective past (1946/1970, pp. 144-145).

\section{Archetypes as carriers of the collective human past}

If the unconscious is, for Jung (1946/1970), a historical formation (pp. 144145), then its contents, the archetypes, are also historically conditioned. This makes the archetypal image as it is manifested in outer events and cultural artifacts a rich source of historical material centering on a particular theme. In "Analytical Psychology and Education," Jung (1928/1970) hypothesizes that the collective

\footnotetext{
${ }^{14}$ Jung (1931/1960) specifies, however, that the unconscious is not "merely conditioned by history" (p. 157). The unconscious is alive, and potentially creative. The unconscious transcends "her own historical conditions in her acts of creation" (ibid.). We notice here a tension in Jung's definitions of the collective unconscious as being informed by the history of humanity on the one hand and transcending history on the other. A similar tension can be found in Jung's definition of archetypes (Shamdasani, 2003/2004, p. 238).
} 
unconscious consists "of the structural deposits or equivalents of psychic activities which were repeated innumerable times in the life of our ancestors" (p. 117). During a seminar on Nietzsche's Zarathustra, Jung (1988) defines archetypes as images that represent "typical situations of great and vital importance, which have repeated themselves in the course of history innumerable times" (p. 21). The psychic fragments or traces, therefore, that become a part of, and define, the archetype, were once real historical situations (Shamdasani, 2003/2004, p. 238).

Archetypes are built upon, encapsulate and shape the history of a particular theme, instinct pattern, or psychic disposition. Jung (1963/1989) characterizes images of the anima, for instance, as possessing a "strongly historical character" (p. 286). As a personification of the unconscious, eternal image of woman residing within men (Jung, 1928/1970a, p. 198), the anima image stretches back into prehistory, "embodies the contents of the past," and presents to the individual those elements of the past of which he is not consciously aware. The anima further "carries" the past that still lives, psychologically, in the individual (Jung, 1963/1989, p. 286). Jung (1959/1978) describes shadow in a similar manner. "The shadow," Jung explains, "is that hidden, repressed, for the most part inferior and guilt-laden personality whose ultimate ramifications reach back into the realm of our animal ancestors and so comprise the whole historical aspects of the unconscious" (p. 266). He further remarks that "the historical factor" attaches itself to all archetypes. Life as we know it has changed little since time immemorial, and the "same physiological and psychological processes that have been man's for hundreds of thousands of years still endure." This provides humanity with the profound intuition of its "eternal continuity" (Jung, 1928/1953, p. 190).

By no means am I saying that Jung's intimations of how the past lives on in the psyches of contemporaries and how he understands "history" (ultimately as a function of the unconscious [Lu, 2011]) are either correct or would even be entertained by practicing historians today. It may be the case that Jung brings a productive modification of these ideas, though that remains to be proven. It is clear, however, that, for Jung, archetypes link the living past with the present. Given Jung's extensive evocation of "history" and the historical method throughout his writings (ibid.), it would be wrong to ignore the extent to which Jung envisioned analytical psychology as, partially, a "historical" endeavour. By extension, further study on how Jung's psychology may be adapted to comment upon historical phenomena and culture - to "do" history rather than merely thinking about it - is indeed warranted. The danger lies, however, in presenting either universalizing discourses that diminish the contextual factors converging to create historical moments or psychologizing narratives that may reduce historical events to nothing but manifestations of psychological processes. It is beyond the scope of this paper to comment extensively on the problems that may arise when applying analytical 


\section{$17 L u$}

psychological concepts to interpret the past, though some difficulties have been noted in previous publications $(\mathrm{Lu}, 2011 ; 2013)$.

I would like to return to the problem of history's and analytical psychology's conflicting epistemologies. I agree with Pietikainen that the major stumbling block preventing greater dialogue between cultural studies and analytical psychology (and, by extension, the discipline of history) is Jung's archetypal theory, especially when an archetype's universal character and a priori status are overemphasized. When this definition of archetypes is contrasted with the ways in which Jung defined them historically, we encounter an additional tension that, Shamdasani (2003/2004) notes, Jung was unable to resolve during his lifetime (pp. 237-238). My contention is that Pietikainen attempted to provide one such resolution and that many Jungian scholars have ignored it to their detriment, especially if the aim is to conduct responsible "Jungian applications" dealing with culture and society.

The epistemological conflict between history and analytical psychology can be stated as follows: whereas history for the most part deals with the realities of the outer world, Jungian psychology is largely concerned with the realities of the inner world, and the "inner dimensions" of events and the psychic traces they leave behind. ${ }^{15}$ The existing gulf between what analytical psychology seeks to know and the epistemological parameters maintained by most practicing historians means that analytical psychology, if it is to contribute to historical discourses, must make a conscious shift to emphasizing its inbuilt potential to engage, integrally and responsibly, analyses of the collective.

Pietikainen realized this and tried to provide one framework in which such a shift could take place. His original view, before his frustration with his detractors' responses set in, was that Jungian psychology provided a much-needed emotive dimension to historical studies that, to some degree, is lacking in the discipline. Analytical psychology could thus balance an overly cognitive concentration on outer phenomena with attention to the "inner" or psychological aspects of history. More specifically, if I am reading Pietikainen correctly, Jung's distinction between archetype and archetypal image may provide a tool to enable us to say something general about the past, without losing sight of the particular. "There is a distinct potentiality," Pietikainen (1998) writes, "in Jung's psychology to make a contribution to this paradigm [of cultural studies] with its emphasis on emotional,

\footnotetext{
${ }^{15}$ One could argue, however, that Jung was equally interested in a rational approach and the realities of the outer world, though not necessarily from an historical perspective. In his early work at the Burghölzli, Jung sought to apply experimental psychology to psychiatry. I would maintain, however, that he was still largely focused on uncovering the workings of the inner world as manifested in outer reality (most notably his schizophrenic patients) by employing a specific scientific method. This approach would, moreover, become less prominent, especially in Jung's later work.
} 
numinous, pathological and other 'abnormal' yet common aspects of human life" (p. 339).

Pietikainen additionally offers another possible way in which analytical psychology could enrich historical studies. Archetypes themselves could become the object of study rather than the hermeneutic lens or tool. If archetypal theory is reconceptualized with Cassirer's symbolic forms in mind as Pietikainen suggests, archetypes themselves become symbolic manifestations of cultural life and collective mental phenomena. Thinking about archetypes in this way would arguably heighten the interest of historians (ibid., p. 341). In aiming to show the applicability of analytical psychology to cultural studies and realizing the tension in Jung's definition of archetypes (as either universal or culturally conditioned), Pietikainen indirectly identifies and addresses the epistemological gulf between the disciplines of history and analytical psychology by calling for a revision of the archetypal hypothesis itself-one, I have argued, that is not completely unwarranted given Jung's consistent evocation of "history" and the intimations of a historical method in his work. Pietikainen's respondents, however, are adamant that the tension in Jung's definition of archetypes should be maintained and that it would be a mistake to ignore Jung's more biological conceptualizations. Yet, from the perspective of history's epistemology, to argue for something's a priori status, be it an event or mental state, is to ignore the very historical questions with which historians are concerned. The salient question to ask is as follows: Given Jung's proclivity to stress a definition of archetypes based on their a priori nature, is there sufficient evidence to justify the development of an archetypal methodology that caters specifically to historical and cultural analysis? I hope that my analysis of the "historical" aspects of Jung's theory prompts us to say "yes." In my opinion, the future of Jungian applications to the social sciences conducted in the academy depends on it.

\section{Conclusion}

I have argued that given the extent to which Jung evoked history in defining key concepts, the moments he displayed a keen appreciation for contextual analysis, and his method of seeking out historical parallels of psychic material, we cannot dismiss the possibility that Jung's psychology, especially his archetypal hypothesis, can be reconfigured to emphasize its intrinsic inclination toward historical and cultural analysis. Analytical psychology's epistemology as conceived by Jung borrows, to some degree but by no means unproblematically, from history's epistemology or, at the very least, what Jung believes to be a "historical" approach. Pietikainen's argument, therefore, is not unfounded and deserves greater attention.

Since Jung (1959/1978) himself admitted his lack as a historian (pp. ix-xi) and never consciously set out to write historical works (Pietikainen, 1998), what is 


\section{$19 L u$}

required are case studies of historians who have mobilized Jungian ideas in their histories. Such case studies would allow us to extrapolate how a distinctly Jungian approach to interpreting the past might look, albeit mediated by the historian's specific interpretation of analytical psychology. I have already made one such attempt, exploring the extent to which analytical psychology informed Arnold J. Toynbee's theory of the rise and fall of civilizations ( $\mathrm{Lu}, 2013)$.

Jungian psychology may be able to contribute to specific areas of the historical enterprise, particularly historiography, defined as how historians have written and narrated the past (Bentley, 1999/2005; Tucker 2009/2011). Chris Lorenz (1999) crucially adds, however, that historiography is about not just "the critical history of historical writing." It is also concerned with "examining how and why historians have thought about the past" (p. 29). In this regard, Jungian psychology may help historians be more aware of their own subjectivity-why they are writing on a certain subject or taking a certain position. Being aware of one's own motivations and complexes, and what the histories one writes may attempt to solve, is potentially liberating and informative. There is, further, a largely unaddressed problem of historical methodology to which analytical psychology can speak. Primary sources are mostly regarded by historians as documents that say something about collective life, and it is up to the historian to determine what that is. The subject matter of sources may concern socio-cultural phenomena, but many are written by individuals and are consequently inherently subjective. Similarly, archivists - who determine what is to be preserved and destroyed in both private and public collections - are individuals whose choices are shaped by their own subjectivity. To understand a past to which the author of a source is referring, as well as why the source exists today, one needs to know about individuals. Depth psychology in general provides a framework for understanding individuals - one that helps us to grasp how motives, both conscious and unconscious, contribute to the documents individuals produce and the decisions they make to preserve or destroy particular fragments of the past. Moreover, since the past is comprised of individuals and history, in large part, is about individual human beings who lived in the past, an attempt to understand them without an adequate psychological lens is to miss a significant part of their overall makeup, identity, and experience. Analytical psychology provides the historian with such a perspective. If we adopt a more postmodern view of history (Jenkins, 1991/2008; Munslow, 1997/2006) and conceive of it as a collection of different narratives told about the past that stimulate new thinking and innovative approaches, analytical psychology also contributes a potentially compelling narrative.

What I believe is required, then, is the building of a strong foundation for future work - studies staying close to the sources, attentive to historical debates and 
avoiding the temptation to engage in "wild psychoanalysis." Such investigations would be concerned with doing psychoanalytic history rather than psychohistory. A psychohistory that ignores history's epistemology is untenable and a history that ignores the unconscious dimension of reality is incomplete. By working at the less magical interface between the disciplines of history and analytical psychology, future Jungian discourses might responsibly offer a subtle (but by no means ineffective) perspective contributing to a more holistic understanding of the past and how historians narrate and imagine that very past.

\section{Reference List}

Abraham, N. \& Torok, M. (1994). The shell and the kernel. (N. T. Rand, Ed. and Trans.) Chicago, IL: The University of Chicago Press.

Ancelin Schützenberger, A. (1998/2009). The ancestor syndrome. Hove, East Sussex: Routledge.

Armstrong, D. (2005). The "organization-in-the-mind:" Reflections on the relation of psychoanalysis to work institutions. In R. French (Ed.), Organizations in the mind pp. 2943). London: Karnac.

Barzun, J. (1974). Clio and the Doctors. Chicago, IL: The University of Chicago Press.

Behr, H. and Hearst, L. (2005). Group analytic psychotherapy. London: Whurr.

Bentley, M. (1999/2005). Modern historiography: An introduction. London: Routledge.

Bion, W. R. (1952/1989). Group Dynamics: A Review. In M. Klein et al. (Eds.), New directions in psychoanalysis (pp. 235-247) London: Tavistock.

Bishop, P. (2008). The timeliness and timelessness of the "archaic:" Analytical psychology, "primordial" thought, synchronicity. Journal of Analytical Psychology, 53, 501-523.

Briggs, R. (1996). Witches \& neighbours. London: HarperCollins Publishers.

Burckhardt, J. (1860/1995). The civilization of the renaissance in Italy. London: Phaidon.

Carr, E. H. (1961/1990). What is history? (2 ${ }^{\text {nd }}$ ed.). London: Penguin Books.

Clarke, J. J. (1992). In search of Jung. London: Routledge.

Clarke, J. J. (1994). Jung and eastern thought. London: Routledge.

Coward, H. (1985). Jung and eastern thought. Albany, NY: State University of New York Press.

de Angulo, X. (1977/1978). Comments on a doctoral thesis. In W. McGuire and R. F. C. Hull (Eds.), C. G. Jung speaking (pp. 205-218). London: Thames and Hudson.

Demos, J. (1982). Entertaining satan. Oxford: Oxford University Press.

Dray, W. (1964). Philosophy of history. Englewood Cliffs, NJ: Prentice-Hall, Inc. 
Elms, A. C. (1994). The auntification of C. G. Jung. In Uncovering Lives (pp. 51-70). Oxford: Oxford University Press.

-----. (2003). Sigmund Freud, psychohistorian. The Annual of Psychoanalysis, 31, 65-78.

Elton, G. R. (1969/1987). The practice of history. London: Fontana Press.

Evans, R. J. (1997). In defence of history. London: Granta Books.

Evans, R. J. (2002). Telling lies about Hitler. London: Verso.

Foulkes, S. H. (1965/1980). Psychodynamic processes in the light of psychoanalysis and group analysis. In S. Scheidlinger (Ed.), Psychoanalytic group dynamics (pp. 147-167) New York: International Universities Press.

Freud, S. \& Jung, C. G. (1974). The Freud/Jung Letters. W. McGuire (Ed.). R. Manheim and R. F. C. Hull (Trans.). Princeton, NJ: Bollingen Series XCIV, Princeton University Press.

Frosh, S. (2010). Psychoanalysis outside the clinic. Basingstoke, Hampshire: Palgrave Macmillan.

Gossman, L. (2000). Basel in the age of Burckhardt. Chicago, IL: University of Chicago Press.

Green, A. (2008). Cultural history. Basingstoke, Hampshire: Palgrave Macmillan.

Hinshelwood, R. D. (1997). Attacks on reflective space. In M. Pines and V. L. Schermer (Eds.), Ring of Fire (pp. 86-106). London: Routledge.

Hogenson, G. B. (1998). Response to Pietikainen and Stevens. Journal of Analytical Psychology, 43, 357-372.

Hunt, H. T. (2012). A collective unconscious reconsidered: Jung's archetypal imagination in the light of contemporary psychology and social science. In Journal of Analytical Psychology, 57, 76-98.

Huskinson, L. (2013). Housing complexes: Redesigning the house of psyche in light of a curious mistranslation of C. G. Jung appropriated by Gaston Bachelard. International Journal of Jungian Studies, 5(1), 64-80.

Jacques, E. (1953). On the dynamics of social structure. Human Relations, 6(1), 3-24. Jenkins, K. (1991/2008). Re-thinking history. London: Routledge.

Jordanova, L. (2000/2006). History in practice ( ${ }^{\text {nd }}$ ed.). London: Hodder Arnold.

Jones, R. A. (2007). A discovery of meaning: The case of C. G. Jung's house dream. Culture \& Psychology, 13, 203-230.

Jung, C. G. (1911/1989). Contributions to symbolism. In W. McGuire (Exec. Ed.), Sir H. Read, M. Fordham, G. Adler (Eds.). Collected works volume 18: The symbolic life. (R. F. C. Hull, Trans.). (p. 446). Princeton, NJ: Princeton University Press.

Jung, C. G. (1918/1970). The role of the unconscious. In W. McGuire (Exec. Ed.), Sir 
H. Read, M. Fordham, G. Adler (Eds.). Collected works volume 10: Civilizations in transition. (R. F. C. Hull, Trans.). (pp. 3-28). London: Routledge.

Jung, C. G. (1925/1990). Analytical psychology: Notes of the seminar given in 1925. (W. McGuire, Ed.). London: Routledge.

Jung, C. G. (1928/1953). The relations between the ego and the unconscious. In W. McGuire (Exec. Ed.), Sir H. Read, M. Fordham, G. Adler (Eds.). Collected works volume 7: Two essays on analytical psychology. (R. F. C. Hull, Trans.). (pp. 121-239). London: Routledge.

Jung, C. G. (1928/1970). Analytical psychology and education. In W. McGuire (Exec. Ed.), Sir H. Read, M. Fordham, G. Adler (Eds.). Collected works volume 17: The development of personality. (R. F. C. Hull, Trans.). (pp. 63-132). London: Routledge.

Jung, C. G. (1928/1970a). Marriage as a psychological relationship. In W. McGuire (Exec. Ed.), Sir H. Read, M. Fordham, G. Adler (Eds.). Collected works volume 17: The development of personality. (R. F. C. Hull, Trans.). (pp. 187-201). London: Routledge.

Jung, C. G. (1929/1957). Commentary on "The secret of the golden flower." In W. McGuire (Exec. Ed.), Sir H. Read, M. Fordham, G. Adler (Eds.). Collected works volume 13: Alchemical studies. (R. F. C. Hull, Trans.). London: Routledge.

Jung, C. G. (1931/1960). The structure of the psyche. In W. McGuire (Exec. Ed.), Sir H. Read, M. Fordham, G. Adler (Eds.). Collected works volume 8: The structure and dynamics of the psyche. (R. F. C. Hull, Trans.). (pp. 139-158). London: Routledge.

Jung, C. G. (1934/1959). Archetypes of the collective unconscious. In W. McGuire (Exec. Ed.), Sir H. Read, M. Fordham, G. Adler (Eds.). Collected works volume 9i: The archetypes and the collective unconscious. (R. F. C. Hull, Trans.). (pp. 3-41). London: Routledge.

Jung, C. G. (1936/1988). Wotan. In Essays on Contemporary Events (pp. 10-24). London: Ark Paperbacks.

Jung, C. G. (1936/1989). The Tavistock lectures. In W. McGuire (Exec. Ed.), Sir H. Read, M. Fordham, G. Adler (Eds.). Collected works volume 18: The symbolic life. (R. F. C. Hull, Trans.). (pp. 5-182). Princeton, NJ: Princeton University Press.

Jung, C. G. (1938/1959). Psychological aspects of the mother archetype. In W. McGuire (Exec. Ed.), Sir H. Read, M. Fordham, G. Adler (Eds.). Collected works volume 9i: The archetypes and the collective unconscious. (R. F. C. Hull, Trans.). (pp. 75-110). London: Routledge.

Jung, C. G. (1943/1966). Psychotherapy and a philosophy of life. In W. McGuire (Exec. Ed.), Sir H. Read, M. Fordham, G. Adler (Eds.). Collected works volume 16: The practice of psychotherapy. (R. F. C. Hull, Trans.). (pp. 76-83). London: Routledge.

Jung, C. G. (1946/1970). The gifted child. In W. McGuire (Exec. Ed.), Sir H. Read, M. Fordham, G. Adler (Eds.). Collected works volume 17: The development of personality. ( $\mathrm{R}$. F. C. Hull, Trans.). (pp. 133-145). London: Routledge.

Jung, C. G. (1947/1960). On the Nature of the Psyche. In W. McGuire (Exec. Ed.), Sir H. Read, M. Fordham, G. Adler (Eds.). Collected works volume 8: The structure and dynamics of the psyche. (R. F. C. Hull, Trans.). (pp. 159-234). London: Routledge.

Jung, C. G. (1947/1970). Preface to "Essays on contemporary events.” In W. McGuire 
(Exec. Ed.), Sir H. Read, M. Fordham, G. Adler (Eds.). Collected works volume 10:

Civilizations in transition. (R. F. C. Hull, Trans.). (pp. 177-178). London: Routledge.

Jung, C. G. (1953/1989). Foreword to Perry: “The self in psychotic process.” In W.

McGuire (Exec. Ed.), Sir H. Read, M. Fordham, G. Adler (Eds.). Collected works volume 18: The symbolic life. (R. F. C. Hull, Trans.). (pp. 353-356). Princeton, NJ: Princeton University Press.

Jung, C. G. (1956/1976). Collected works volume 5: Symbols of transformation. (W. McGuire [Exec. Ed.], Sir H. Read, M. Fordham, G. Adler [Eds.] \& R. F. C. Hull [Trans.]). Princeton, NJ: Princeton University Press.

Jung, C. G. (1958/1970). A psychological view of conscience. In W. McGuire (Exec. Ed.), Sir H. Read, M. Fordham, G. Adler (Eds.). Collected works volume 10: Civilizations in transition. (R. F. C. Hull, Trans.). (pp. 437-455). London: Routledge.

Jung, C. G. (1959/1978). Collected works volume 9ii: Aion. (W. McGuire [Exec. Ed.], Sir H. Read, M. Fordham, G. Adler [Eds.] \& R. F. C. Hull [Trans.]). Princeton, NJ: Princeton University Press.

Jung, C. G. (1963/1989). Memories, Dreams, Reflections. (R. Winston \& C. Winston, Trans.). New York: Vintage Books.

Jung, C. G. (1973). Letters volume 1: 1906-1950. (G. Adler and A. Jaffé [Eds.] \& R. F. C. Hull [Trans.]). New Jersey: Princeton University Press.

Jung, C. G. (1988). Nietzsche's Zarathustra: Notes on the seminar given in 1934-1939 by C. G. Jung (2 vols.). (J. L. Jarrett, Ed.). London: Routledge.

Lorenz, Chris. (1999). Comparative historiography: problems and perspectives. History and Theory, 38(1), 25-39.

Lu, K. (2011). Jung and history. In G. Heuer (Ed.), Sexual Revolutions (pp. 11-34). London: Routledge.

Lu, K. (2013). A Jungian psychohistory: A. J. Toynbee's use of analytical psychology in his theory of civilizations. International Journal of Jungian Studies, DOI:10.1080/19409052.2012.754364

Marlan, S. (2006). Alchemy. In R. Papadopoulos (Ed.), The Handbook of Jungian Psychology (pp. 263-295). London: Routledge.

Marwick, A. (1995). Two approaches to historical study: The metaphysical (including "postmodernism") and the historical. Journal of Contemporary History, 30(1), 5-35.

Marwick, A. (2001). The new nature of history. Basingstoke, Hampshire: Palgrave Macmillan.

McFarland Solomon, H. (1998). Response to Petteri Pietikainen's “Archetypes as symbolic forms." Journal of Analytical Psychology, 43, 373-377.

Mogenson, Greg. (1999). Psyche's archetypes: A response to Pietikainen, Stevens, Hogenson and Solomon. Journal of Analytical Psychology, 43, 125-133.

Munslow, A. (1997/2006). Deconstructing history (2 ${ }^{\text {nd }}$ ed.). London: Routledge. 
Noll, R. (1994/1997). The Jung cult. New York: Free Press Paperbacks.

Pietikainen, P. (2001). Dynamic psychology, utopia and escape from history: The case of C. G. Jung. Utopian Studies, 12(1), 41-55.

Pietikainen, P. (1998). Archetypes as symbolic forms. Journal of Analytical Psychology, $43,325-343$.

Pietikainen, P. (1998a). Response to Hester McFarland Solomon, George B. Hogenson and Anthony Stevens. Journal of Analytical Psychology, 43, 379-388.

Progoff, I. (1953/1985). Jung's psychology and its social meaning. New York: Dialogue House Library.

Purkiss, D. (1996/1997). The witch in history. London: Routledge.

Roesler, C. (2012). Are archetypes transmitted more by culture than biology? Questions arising from conceptualizations of the archetype. Journal of Analytical Psychology, 57, 223-246.

Roper, L. (1994). Oedipus and the devil. London: Routledge.

Rowland, S. (2007). Response to Robert A. Segal's “Jung and Lévy-Bruhl.” Journal of Analytical Psychology, 52, 659-665.

Samuels, A. (1996). The future of Jungian studies: A personal agenda. In M. Stanton and D. Reason (Eds.), Teaching Transference. London: Rebus Press.

Segal, R. A. (2007). Jung and Lévy-Bruhl. Journal of Analytical Psychology, 52, 635658.

Shamdasani, S. (1995). Memories, Dreams, Omissions. Spring, 57, 115-137.

Shamdasani, S. (2003/2004). Jung and the making of modern psychology. Cambridge: Cambridge University Press.

Sherry, J. (2010/2012). Carl Gustav Jung: Avant-garde conservative. Basingstoke, Hampshire: Palgrave Macmillan.

Skynner, R. (1991). Institutes and how to survive them. In J. R. Schlapobersky (Ed.), Institutes and how to survive them (pp. 189-211). London: Tavistock/Routledge.

Stannard, D. E. (1980). Shrinking history. Oxford: Oxford University Press.

Stevens, A. (1998). Response to P. Pietikainen. In Journal of Analytical Psychology, 43, $345-355$.

Tucker, A. (2004). Our knowledge of the past. Cambridge: Cambridge University Press.

Tucker, A. (2009/2011). Introduction. In A. Tucker (Ed.), A companion to the philosophy of history and historiography (pp. 1-6). Oxford: Wiley-Blackwell.

Warren, J. (1999/2004). History and the historians. London: Hodder \& Stoughton.

Wolff-Windegg, P. (1976). C. G. Jung-Bachochen, Burckhardt, and Basel. Spring, 13747. 